\title{
ROLA KOMERCJALIZACJI WIEDZY W IDENTYFIKACJI MOŻLIWOŚCI BIZNESOWYCH I ROZWOJU NOWYCH PRODUKTÓW NA PRZYKŁADZIE WSPÓLPRACY UCZELNI Z FIRMĄ HIPOVET LABORATORIUM
}

\author{
Matgorzata Grzegorczyk \\ Uniwersytet Łódzki
}

\begin{abstract}
Abstrakt
Artykuł jest głosem w dyskusji na temat roli współpracy środowiska nauki i biznesu w celu rozpoznawania możliwości biznesowych i rozwoju nowych produktów. Omawia kwestie wsparcia przedsiębiorstw przez ośrodki naukowe w zakresie wiedzy rynkowej oraz wiedzy technologicznej i wykorzystania współpracy $w$ strategiach rozwoju, ze szczególnym uwzględnieniem strategii rozwoju produktu i dywersyfikacji. W artykule zaprezentowano przypadek współpracy Uniwersytetu Łódzkiego z firmą Hipovet Laboratorium, jedynego polskiego producenta kosmetyków dla koni i małych zwierząt $\mathrm{z}$ nanosrebrem oraz rozwoju nowych produktów przy wsparciu UŁ w zakresie wiedzy rynkowej i technologicznej.

\section{Wprowadzenie}

Rozpoznanie możliwości biznesowych jest istotnym krokiem na drodze komercjalizacji nauki i technologii. Dotyczy w sposób szczególny przedsięwzięć powstających $\mathrm{w}$ oparciu o nowe technologie. Istnieje niewiele naukowych opracowań na ten temat - większość z nich dotyczy trudności z definiowaniem i pomiarem szans biznesowych oraz zarządzania wiedzą [Singh, 2000; Choi, Sheperd, 2004; Park, 2005]. Wiele innowacyjnych pomysłów i wyników badań w zakresie nauk biotechnologicznych pozostaje „na półce”, gdyż nie zidentyfikowano ich możliwości biznesowych. Jednym $\mathrm{z}$ warunków rozwoju przemysłu biotechnologicznego jest usprawnienie mechanizmów komercjalizacji wiedzy i skuteczniejsza współpraca ośrodków naukowych $\mathrm{z}$ firmami. W artykule wykorzystano przykład współpracy pomiędzy uczelnią a firmą działającą $\mathrm{W}$ obszarze produkcji preparatów o właściwościach grzybobójczych i bakteriobójczych do pielęgnacji zwierząt.
\end{abstract}




\section{Strategie rozwoju przedsiębiorstw}

Istnieje wiele systematycznych podejść wspomagających przedsiębiorstwa $\mathrm{w}$ procesie formułowania, wyboru i implementacji strategii rozwoju. Najbardziej rozpowszechnionym jest macierz H. I. Ansoffa, która wskazuje strategiczne opcje rozwoju przedsiębiorstwa jako wynik relacji zachodzących pomiędzy rynkiem a produktem. Wybór danej strategii, w tym strategii rozwoju nowego produktu, zależy m.in. od stopnia nasycenia rynku produktem, skłonności do podejmowania ryzyka, intensywności zmian w otoczeniu, ograniczeń czasowych i zasobów firmy. Najpowszechniejsza z punktu widzenia procesów komercjalizacji strategia rozwoju nowego produktu polega na wprowadzeniu nowych, udoskonalonych lub zmodyfikowanych produktów na dotychczasowe rynki, w wyniku zaplanowania i podjęcia zintegrowanych i skoordynowanych działań mających zapewnić przedsiębiorstwu osiagnięcie celów [Rutkowski, 2004]. W ramach teorii innowacji strategia rozwoju produktu Ansoffa oznacza innowację produktową lub tzw. produktowy postęp techniczny. Rozwój nowego produktu oraz nowego rynku w macierzy Ansoffa wyznacza strategia dywersyfikacji. Jest to najbardziej złożony, zaawansowany oraz ryzykowany wariant rozwoju strategii przedsiębiorstwa. Dywersyfikacja oznacza rozwój i wprowadzenie nowych, dotychczas nieoferowanych wyrobów, wytwarzanych z wykorzystaniem istniejących lub nowych technologii, zaspokajających inne potrzeby niż obecne produkty. H. I. Ansoff wyróżnił dywersyfikację horyzontalną, wertykalną, koncentryczną oraz konglomeratową [Ansoff, 1980]. Z punktu widzenia komercjalizacji istotniejszy wydaje się być podział L. Wrigleya na dywersyfikację pokrewną oraz niepokrewną [Wrigley, 1970]. Dywersyfikacja pokrewna występuje, jeśli spełniony jest co najmniej jeden z poniższych warunków:

1) nowy produkt sprzedawany jest na rynkach podobnych do tych, na których firma dotychczas działała, za pomocą podobnych narzędzi mieszanki marketingowej,

2) nowy produkt wytwarzany jest przy użyciu podobnej technologii,

3) nowy produkt związany jest z podobną bazą badawczo-rozwojowa,

4) nowa działalność znajduje się $\mathrm{w}$ tym samym łańcuchu produkcji i sprzedaży.

Dywersyfikacja jest niepokrewna, jeśli nie występuje żaden z powyższych warunków. W literaturze przedmiotu istnieją podobne klasyfikacje strategii nowego produktu, dokonywane na podstawie kryteriów: nowości technologicznej produktu, nowości dla producenta, oryginalności, możliwości budowania przewagi konkurencyjnej. Ze 
względu na ostatnie wymienione kryterium - wartości konkurencyjnej wyróżnia się następujące rodzaje technologii w wymiarze nowości [Strategor, 1995]:

1) technologie bazowe, o słabej wartości konkurencyjnej (dojrzałe, dostępne i szeroko stosowane w branży),

2) technologie kluczowe, będące podstawą konkurencyjności (młode, silnie chronione w przedsiębiorstwach),

3) technologie embrionalne oraz eksperymentalne ( $w$ fazie narodzin, o małym zastosowaniu, rozwojowe - mogą stać się technologiami kluczowymi).

Technologie wytwarzane na podstawie wyników badań naukowych, szczególnie w obszarze life science, zwykle mają charakter technologii eksperymentalnych lub embrionalnych. Ich wdrożenie jest procesem trudnym i złożonym, oznaczającym dla firmy najczęściej realizację strategii dywersyfikacji niepokrewnej, obarczonej największym ryzykiem.

Uwzględniając stopień nowości produktów wprowadzanych na rynek dla nabywców oraz producentów, firma może zastosować strategię modernizacji dotychczasowego produktu, technologicznej modyfikacji dotychczasowego produktu, imitacji produktów konkurencyjnych lub strategię bezwzględnie nowego produktu [Taranko, 2004]. Strategię modernizacji wytwarzanego produktu charakteryzuje niski stopień nowości dla producenta oraz stosunkowo niewiele korzyści dla nabywcy. Podejmowane działania zwykle są reakcją na dotychczasowe niedoskonałości produktu lub zmieniające się preferencje klientów. Mają one na celu przedłużyć rynkowy cykl życia produktu bez radykalnych zmian $\mathrm{w}$ jego funkcjonalności oraz sposobie rozwiązywania problemów klienta. Strategia ta pozwala na rozwój firmy oraz umocnienie pozycji rynkowej poprzez zapewnienie klientom wyższego poziomu zaspokojenia ich potrzeb w drodze dostosowania produktu w aspekcie funkcjonalnym, psychologicznym, estetycznym lub w zakresie usług towarzyszących. Według M. Haffera strategia modernizacji produktu jest najczęściej stosowaną przez firmy strategią rozwoju produktu [Haffer, 1999]. Strategia technologicznej modyfikacji produktu zakłada wysoki stopień nowości produktu dla producenta, przy niewielkim stopniu nowości dla nabywcy. Bywa podejmowana przez producentów pod wpływem zmian obowiązujących wymogów prawnych i jakościowych wobec produktu. Może wspierać realizację strategii przywództwa kosztowego, redukując koszty wytwarzania poprzez zmiany technologii, używanych materiałów, zmiany konstrukcyjne itp. 
$\mathrm{Z}$ kolei strategia imitacji konkurencyjnego produktu polega na adaptowaniu znanej producentowi techniki wytwarzania i przedstawienia na rynku oferty podobnej do produktów oferowanych przez inne firmy. Ta forma rozwoju produktu dotyczy zazwyczaj technologii bazowych, które mają powszechny charakter i są ogólnie dostępne. Najczęściej imitowane są produkty firm zagranicznych, które odnoszą sukcesy na innych rynkach geograficznych. Strategia bezwzględnie nowego produktu cechuje się najwyższym stopniem nowości zarówno dla producenta, jak i nabywcy. Produkty takie dostarczają klientom zupełnie nowych użyteczności, pozwalają zaspokajać nowe potrzeby lub umożliwiają rozwiązywanie problemów klientów w odmienny sposób. Często powstają one wskutek komercjalizacji wyników badań naukowych prowadzonych w firmach lub w ośrodkach badawczo-naukowych. Wytworzenie takiego produktu wymaga zastosowania nowych rozwiązań techniki i technologii, a wprowadzenie na rynek wymaga odmiennych, nowych działań marketingowych.

Istotnym elementem strategii rozwoju produktu jest zarządzanie portfelem produktów i architekturą marki. Cały wachlarz produktów należy uporządkować pod kątem jego stabilności, generowania zysku oraz redukcji ryzyka. Do podstawowych strategii marki zalicza się strategię marki monolitycznej (branded house), strategię marki parasolowej, strategię wielomarkową (house of brands) oraz strategię marki wspierającej submarki. Dobrze ukształtowana architektura marki w zależności od przyjętego modelu może ułatwiać wprowadzanie nowych produktów na rynek, minimalizować koszty promocji i dystrybucji lub zwiększać udziały rynkowe.

\section{Informacja na rynku biotechnologicznym}

Współczesna biotechnologia charakteryzuje się wysoką dynamiką zmian oraz szybkim starzeniem się naukowych i technologicznych informacji. Dodatkowo w praktyce rozwój na rynku biotechnologii, zwykle obejmujący fazę badań przedklinicznych i klinicznych, jest mocno regulowany przez prawo, co tworzy dodatkowe bariery wejścia. Niejednokrotnie zauważyć można zdefiniowany innowacyjny pomysł, który zostaje opatentowany, ale możliwości biznesowe pozostają niezidentyfikowane, co sprawia, że nie zostaje on wdrożony w praktyce. Podstawową rolę $w$ identyfikacji możliwości biznesowych odgrywa informacja [Shane, 2003; Kirzner, 1997]. Jednak naukowcy nie są zgodni co do liniowej zależności pomiędzy ilością posiadanej wiedzy a liczbą identyfikowanych przez przedsiębiorcę możliwości biznesowych [Gaglio, 
Katz, 2001; Holcombe, 2003; Lumpki, Lichtenstein, 2005; Ozgen, Baron, 2007]. W literaturze przedmiotu od lat toczy się dyskusja dotycząca tego, czy większy wpływ ma istniejąca, czy nowa wiedza. Kirzner [1997] uważa, że największy wpływ ma zróżnicowany dostęp do istniejących informacji. Zgodnie z koncepcją Schumpetera [1934] decydujące znaczenie w identyfikacji szans biznesowych ma nowa wiedza. Zmiany czynników makroekonomicznych, w tym politycznych, technologicznych i społecznych, kreują powstawanie nowych informacji, które przedsiębiorcy mogą wykorzystać w celu rekombinacji i wykorzystania zasobów w bardziej efektywny sposób. $\mathrm{Na}$ rynkach zaawansowanych technologicznie do powstania nowych możliwości biznesowych moga prowadzić głównie zmiany istniejących technologii. W literaturze przedmiotu pojawia się także teoria „zdolności absorpcyjnej” przedsiębiorstwa, która odnosi się do umiejętności rozpoznawania zewnętrznych źródeł informacji, asymilacji informacji i wykorzystania jej w zastosowaniach komercyjnych [Cohen, Levinthal, 1990]. Badania prowadzone $\mathrm{w}$ firmie odgrywają zatem podwójną rolę: tworzenia nowej wiedzy, a także wspierania i rozwoju zdolności firmy do absorpcji wiedzy wytworzonej przez innych. Dla rozwoju innowacji istotna jest nie tylko wiedza tworzona $\mathrm{w}$ organizacji, ale także pozyskiwana $\mathrm{z}$ zewnętrznych źródeł, przy czym uznaje się, że wiedza rynkowa jest równie istotna jak wiedza technologiczna [Siegel, Renko, 2012].

W badaniu CEM Instytutu Badań Rynku i Opinii Publicznej zatytułowanym Ocena transferu wiedzy $i$ powiazań sfery $B+R$ oraz instytucji otoczenia biznesu $z$ przedsiębiorstwami [Jerschina, LalikBudzewska, Beźnic, 2009] jako jedną z przyczyn trudności w transferze wiedzy ze świata akademickiego do biznesu przedsiębiorcy podali barierę dostępu do szczegółowej oferty badawczej ośrodków naukowych. Oferta badawcza ośrodków akademickich jest wprawdzie dostępna, ale na bardzo podstawowym poziomie. Wielu przedsiębiorców uważa, że ośrodki naukowe są nastawione praktycznie wyłącznie na innowacje w zakresie procesu technologicznego, a nie na innowacje w zakresie usług (m.in. w zakresie organizacji pracy, marketingu, zarządzania itp.). Tego rodzaju innowacje są obarczone największym ryzykiem i skierowane $\mathrm{w}$ zasadzie tylko do firm produkcyjnych (brak oferty dla firm usługowych). Współpraca przedsiębiorstwo - jednostka badawczo-rozwojowa jest zwykle sformalizowana, objęta stosownymi umowami określającymi zobowiązania każdej ze stron w procesie realizacji projektu. Przedsiębiorcy docierają do jednostek naukowo-badawczych przede wszystkim przez internet lub poprzez własnych pracowników, którzy są absolwentami 
uczelni i wciąż utrzymują z nimi kontakt (wiedzą, gdzie i do kogo zwrócić się z danym problemem). Taki model biznesu jest szczególnie popularny w USA. Uczelnie z zakresu life scence rekrutują pracowników spośród naukowców będących niegdyś pracownikami dużych korporacji biotechnologicznych. Tymczasem w Polsce nadal przeważa model uczelnibunkra, do którego bardzo trudno przedostać się w celu pozyskania wiedzy, w tym informacji na temat najnowszych wyników badań.

\section{Wsparcie biznesu w identyfikacji możliwości biznesowych}

W większości polskich firm biotechnologicznych kluczową rolę odgrywa nie tyle wartość sprzedaży (w skali europejskiej nadal traktowane są jako spółki na początkowym etapie rozwoju), co wartość posiadanych zasobów, w tym głównie aktywów niematerialnych. Do zasobów tych zaliczyć można wiedzę, $w$ tym patenty. Zgodnie $\mathrm{z}$ informacjami Europejskiego Urzędu Patentowego liczba polskich wynalazków klasyfikowanych jako biotechnologiczne rośnie, choć jest to raczej wzrost symboliczny, nadal pozostawiający Polskę w „końcówce Europy” [Ernst\&Young, 2010]. Nie oznacza to jednak, że polska biotechnologia, zarówno ze strony przedsiębiorstw, jak i nauki, nie tworzy wartościowych rozwiązań. Wiele firm pracuje nad innowacyjnymi produktami i często posiada krajowe zgłoszenia lub patenty. Mniejsze firmy często wybierają inne strategie ochrony innowacji, np. ochronę poprzez tajemnicę handlową. Mimo to nadal w wielu przypadkach komercjalizacja kończy się właśnie na zgłoszeniu patentowym, a brak środków i doświadczenia powoduje, że uczelnie nie są w stanie przygotować innowacji do sprzedaży na trudnym rynku nowych technologii. Do barier współpracy zalicza się m.in.:

1) barierę mentalną - brak wzajemnego zrozumienia potrzeb, posługiwanie się innym językiem, inną kulturę podejmowania decyzji, powszechny brak zaufania,

2) konieczność poniesienia przez przedsiębiorstwo dużych nakładów finansowych,

3) stronę formalną współpracy - ogrom pracy administracyjnej, jaką trzeba wykonać, przystępując do współpracy z uczelnią czy inną jednostką badawczo-rozwojową, biurokrację, sformalizowaną komunikację, brak elastyczności,

4) brak informacji, brak aktywnej promocji jednostek badawczorozwojowych i zauważalnych prób aktywnego zwiększenia zakresu współpracy uczelni z przedsiębiorstwami, aktualizacji informacji na temat prowadzonych badań, 
5) utrudnienia systemowe i brak systemowych zachęt dla jednostek badawczo-rozwojowych współpracujących $\mathrm{z}$ przedsiębiorstwami w zakresie wdrażania nowych rozwiązań,

6) brak odpowiedniej oferty ze strony jednostek badawczo-rozwojowych,

7) brak kompetencji po obu stronach.

Przykład współpracy Uniwersytetu Łódzkiego z firmą Hipovet Laboratorium pokazuje, że możliwe jest pokonanie wymienionych powyżej barier. Firma Hipovet Laboratorium powstała w 2003 roku, stawiając sobie za cel stworzenie linii produktów pielęgnacyjnych dla zwierząt, o najwyższej skuteczności i profilu bezpieczeństwa. Do współpracy zaproszono wybitnych polskich weterynarzy, hodowców oraz kosmetologów, co pozwoliło, na podstawie najlepszych światowych wzorców, stworzyć całkowicie polską linię kosmetyków pielęgnacyjnych dla koni. Strategię tę można uznać za strategię rozwoju nowego produktu poprzez imitację. Wysoki poziom nowości dla nabywcy jest efektem braku podobnych rozwiązań na rodzimym rynku i daje wyraźną przewage $\mathrm{w}$ proponowanych korzyściach $\mathrm{w}$ porównaniu z już istniejącymi na rynku produktami. Wieloletnia obecność na rynku, analiza opinii klientów oraz własne doświadczenia pozwoliły firmie na stworzenie nowych, unikatowych preparatów, takich jak płyn dezynfekujący do kopyt, produkty do pielęgnacji wyrobów skórzanych czy linia pielęgnacyjna dla małych zwierząt. Przebojem rynkowym okazały się preparaty pielęgnacyjne dla koni zawierające nanosrebro. Technologia wytwarzania niezmodyfikowanych chemicznie nanocząsteczek miedzi, srebra i złota o zdefiniowanych rozmiarach, opartych na chemicznej redukcji jonów wymienionych metali w obecności substancji stabilizujących, została wypracowana $\mathrm{w}$ ramach badań prowadzonych na Wydziale Chemii Uniwersytetu Łódzkiego. Rozwój współpracy i powstanie spółki spin-off zajmującej się produkcją koloidu nanosrebra został szczegółowo opisany $\mathrm{w}$ studium przypadku Transfer nanotechnologii do firmy spin-off na przyktadzie NPIN s.c. [Trzmielak, 2013]. W procesie komercjalizacji pośredniczyły uczelniane jednostki: Centrum Innowacji Akcelerator Technologii UŁ oraz Centrum Transferu Technologii UŁ. Wyniki badań potwierdziły właściwości bakteriobójcze wytwarzanego nanosrebra, m.in. w leczeniu ran i otarć. W efekcie nawiązano relacje z firmą Hipovet, która wykorzystuje komponent nanosrebra do produkcji nowej linii kosmetyków dla koni. Preparaty pielęgnacyjne firmy Hipovet z linii Silverline wykazują działanie przeciwzapalne, bakteriobójcze i grzybobójcze. Zawarte w nich nanosrebro działa skutecznie na większość szczepów bakterii i grzybów, tym samym zapobiegając infekcjom przy otarciach i pęknięciach skóry. 
Aktywny składnik nanosrebra jest uwalniany stopniowo i utrzymywany przez długi czas na stałym poziomie. Nanosrebro aktywuje swoje działanie już po 30 minutach od nałożenia, dzięki czemu przyspiesza proces leczenia, skutecznie kontroluje infekcje w zakażonych ranach i łagodzi ból. [www.hipovet.com].

Wprowadzając komponent nanosrebra do istniejących produktów dla koni (maść na grudę oraz balsam na otarcia), firma Hipovet realizowała strategię rozwoju nowego produktu poprzez technologiczną modyfikację wytwarzanego produktu - dodanie cząsteczek nanosrebra do oferowanej już na rynku maści. Jednak ta strategia oznaczała nie tylko nowość dla producenta, ale także poprawiała właściwości produktu, zaspokajając tę samą potrzebę na wyższym poziomie jakości (skuteczności). Dodatek nanosrebra wzmocnił właściwości antybakteryjne produktów. Poprawiła się jakość, skuteczność oraz wydłużył czas działania preparatu. Zmiana miała zatem charakter nie tylko nowości technologicznej w procesie wytwarzania produktu, ale też formę modernizacji produktu $\mathrm{w}$ zakresie lepszego zaspokajania potrzeb klienta.

W celu optymalizacji portfela produktów Hipovet realizuje strategię marki monolitycznej, polegającą na znakowaniu jedną marką wszystkich produktów. Strategia marki monolitycznej, obok marki parasolowej, jest najbardziej popularna w obszarze life science. Marki parasolowe można dostrzec w promocji produktów granicznych - lek/suplement, lek/wyrób medyczny oraz leków OTC/Rx. Na rynku kosmetyków częściej spotyka się strategię marki linii produktów oraz strategię wielomarkową (house of brands). Marka monolityczna pozwala firmie Hipovet koncentrować reputację i zaufanie nabywców wytworzone przez firmę we wszystkich działaniach i produktach. Firma jest na etapie budowania siły marki, rozwoju i umacniania swojej pozycji na obsługiwanych rynkach. Taki model architektury marki zapewnia ograniczenie kosztów promocji i dystrybucji oraz pozwala uzyskać efekty synergiczne wizerunku. Klientowi łatwiej jest zrozumieć i przywołać z pamięci jedną silną markę komunikowaną przez długi okres w stosunku do różnych produktów niż kilkanaście marek z ich odrębnymi asocjacjami. Rozpoznawalność marki $\mathrm{w}$ grupie docelowej ułatwia firmie wprowadzanie kolejnych nowych produktów. W miarę dalszego rozwoju liczby produktów w portfelu firma powinna rozważyć strategię marki parasolowej, tworząc submarki wspierane przez markę wiodącą Hipovet. W przyszłości, chcąc wprowadzać na rynek produkty skierowane do innych grup docelowych, niespójne wizerunkowo $\mathrm{z}$ istniejącymi (np. kosmetyki dla ludzi), firma powinna rozważyć wprowadzenie nowych marek do portfela, aby ustrzec 
się przed mylącym pozycjonowaniem (Hipovet - kosmetyki dla koni i małych zwierząt) i rozmyciem wizerunku marki wiodącej.

W przypadku firmy Hipovet podkreśla się otwartość zespołu na nowości oraz aktywne poszukiwanie źródeł innowacji i pomysłów na nowe produkty. Obok otwartości kadry zarządzającej na nowości do czynników wpływających na wprowadzenie innowacji w przedsiębiorstwie zalicza się:

1) wewnętrzną potrzebę wprowadzania zmian, rozwoju, ciągłego unowocześniania produktów i usług,

2) myślenie strategiczne, analizę i zrozumienie rynku, obserwowanie zachodzących zmian, przewidywanie rynkowych trendów - wiedzę rynkowa,

3) potencjał twórczy przedsiębiorstwa - wiedzę technologiczną i kompetencje, umiejętność pozyskiwania informacji i przełożenia posiadanej wiedzy technologicznej i rynkowej na projekt działania innowacyjnego,

4) determinację $\mathrm{w}$ dążeniu do wytyczonego celu (próby wprowadzania innowacji często napotykają na różnego rodzaju bariery).

Firma Hipovet jest otwarta na innowacje i chce wdrażać nowe produkty. Jednostki wsparcia transferu wiedzy Uniwersytetu Łódzkiego podjęły się doradztwa oraz identyfikacji potrzeb przedsiębiorstwa i możliwych kierunków rozwoju przy współpracy z uczelnią, dzieląc się wiedzą rynkową oraz znajomością oferty badawczej UŁ. Efektem współpracy było opracowanie nowego zastosowania dla nanosrebra. Obecnie, dzięki współpracy firmy z Akceleratorem Technologii UŁ oraz Centrum Transferu Technologii UŁ, zidentyfikowano nowe możliwości komercjalizacji wyników badań i rozwoju firmy. Prowadzone są rozmowy, stworzona została podstawa współpracy i rozwoju nowych produktów z wykorzystaniem olejków eterycznych w kosmetykach dla zwierząt.

Podstawowym problemem rozwoju współpracy pomiędzy uczelniami a biznesem jest rozproszenie informacji. Bazy danych na temat innowacyjnych wyników są mało znane i słabo promowane. Zgromadzenie kompletnych danych na temat nowych rozwiązań i technologii opracowywanych dla poszczególnych branż lub dotyczących konkretnych zagadnień wymaga dużo czasu i determinacji. Przedsiębiorcy mają problemy z dotarciem do przełomowych innowacji opracowywanych na uczelniach. Wśród części twórców innowacji panuje obawa przed podawaniem do publicznej wiadomości informacji na temat nowych rozwiązań - pozostają one tajemnicą firmy bądź jednostki badawczorozwojowej, w której powstały. Niechęć do dzielenia się posiadaną wiedzą jest głównie wynikiem obaw przed kradzieżą pomysłu. Działania uczelni 
i instytucji oraz organizacji powołanych do wspierania innowacyjnych przedsiębiorstw nadal mają charakter pasywny i niewystarczający.

\section{Konkluzje}

Biotechnologia jako interdyscyplinarna dziedzina nauki i techniki oferuje bezpośrednie i potencjalne możliwości wspierania wzrostu gospodarczego, zatrudnienia i konkurencyjności. Ma zasadnicze znaczenie w rozwoju ochrony zdrowia, kreowaniu wzrostu gospodarczego, tworzeniu nowych miejsc pracy, dbałości o zrównoważony rozwój [http://www.nauka.gov.pl/nauka/polityka-naukowa-panstwa/biotechnologia/biotechnologia/]. Kraje rozwinięte już dawno dostrzegły motoryczną funkcję biotechnologii. W Polsce biotechnologia wciąż ma charakter wschodzący, choć należy do najszybciej rozwijających się sektorów. Polska posiada bardzo ważny zasób dla rozwoju przemysłu biotechnologicznego wykształcony kapitał ludzki. Jednak warunkiem rozwoju przemysłu biotechnologicznego jest większy udział polskiej kadry naukowej oraz przedsiębiorstw, głównie $z$ branży farmaceutycznej i chemicznej, w procesach komercjalizacji opartych na współpracy i transferze wiedzy. Konieczne jest poszukiwanie rozwiązań, które pozwolą na dokonanie transferu wiedzy, doświadczenia i wyników badań.

\section{Referencje}

1. Ansoff H. I., Corporate Strategy, McGraw-Hill, New York, 1980.

2. Choi Y. R., Sheperd D. A., Entrepreneurs' decisions to exploit opportunities, "Journal of Management", vol. 30, no. 3, 2004.

3. Cohen W. M., Levinthal D. A., Absorptive capacity: a new perspective on learning and innovation, "Administrative Science Quarterly", vol. $5,1990$.

4. Ernst\&Young, Beyond Borders - Global Biotechnology Report, London.

5. Gaglio C. M., Katz J. A. (2001): The psychological basis of opportunity identification: entrepreneurial alertness, "Small Business Economics, vol. 16, no.2, 2010.

6. Haffer M., Strategie nowego produktu polskich przedsiębiorstw, „Marketing i Rynek”, nr 2, 1999.

7. Holcombe R. G., The origins of entrepreneurial opportunities, "Review of Austrian Economics", vol. 16, no. 1, 2003.

8. http://www.nauka.gov.pl/nauka/polityka-naukowa-panstwa/biotechno logia/biotechnologia/. 
9. Jerschina J., Lalik-Budzewska D., Beźnic S., Ocena transferu wiedzy $i$ powiqzań sfery $B+R$ oraz instytucji otoczenia biznesu $z$ przedsiębiorstwami- glówne wnioski, materiały CEM Instytutu Badań Rynku i Opinii Publicznej, Kraków, 2009.

10. Kirzner I., Entrepreneurial discovery and the competitive market process. An Austrian approach, "Journal of Economic Literature", vol. 35, 1997.

11. Lumpkin G. T., Lichtenstein B. B., The role of organizational learning in the opportunity-recognition process, "Entrepreneurship Theory and Practice", vol. 29, no. 4, 2005.

12. Ozgen E., Baron R. A., Social sources of information in opportunity recognition: effects of mentors, industry networks, and professional forums, "Journal of Business Venturing", vol. 22, no. 2, 2007.

13. Park J. S., Opportunity recognition and product innovation in entrepreneurial hi-tech start-ups: a new perspective and supporting case study, "Technovation", vol. 25, 2005.

14. Rutkowski I., Wymiary powodzenia strategii rozwoju nowego produktu, [w:] Kall J., Sojkin B., Zarzqdzanie produktem w warunkach globalizacji gospodarki, Wydawnictwo AE w Poznaniu, Poznań, 2004.

15. Schumpeter J. A., The Theory of Economic Development, Transaction Publisher, London, 1934.

16. Shane S., A General Theory of Entrepreneurship. The Individualopportunity Nexus, Edward Elgar, Cheltenham, 2003.

17. Siegel D. S., Renko M., The role of market and technological knowledge in recognizing entrepreneurial opportunities, Management Decision”, vol. 50, no. 5, 2012.

18. Singh R. P., Entrepreneurial Opportunity Recognition through Social Networks, Garland Publishing, New York, 2000.

19. Strategor, Zarzqdzanie firmq. Strategie, struktury, decyzje, tożsamość, PWE, Warszawa, 1995.

20. Taranko T., Strategie nowego produktu i zwiqzane z nimi ryzyko, [w:] Kall J., Sojkin, B., Zarzqdzanie produktem $w$ warunkach globalizacji gospodarki, Wydawnictwo AE w Poznaniu, Poznań, 2004.

21. Trzmielak D. M., Komercjalizacja wiedzy i technologii - determinanty i strategie, Wydawnictwo Uniwersytetu Łódzkiego, Łódź [w druku], 2013.

22. Wrigley L., Divisional Autonomy and Diversification, Harvard University Press, Boston, 1970. 


\begin{abstract}
This article is a voice in the debate on the role of collaboration between academic and business environment in order to identify market opportunities and the development of new products. It discusses issues of research centers support for the enterprises in the field of market knowledge and technological knowledge, with particular emphasis on product development strategy and diversification. This article presents a case of Hipovet Laboratorium, the only Polish manufacturer of cosmetics for horses and small animals including nanosilver and development of new products with the support of the University of Lodz, Chemistry Faculty.
\end{abstract}

